\begin{tabular}{|l|l|}
\hline Jurnal Bimbingan dan Konseling Ar-Rahman \\
Volume 6, Nomor 2, Tahun 2020 \\
Tersedia Online: http://ojs.uniska.ac.id/index.php/BKA \\
e-ISSN 2477-6300
\end{tabular}

\title{
HUBUNGAN ANTARA PERSEPSI SISWA TERHADAP BIMBINGAN DAN KONSELING DENGAN MINAT SISWA MENGIKUTI KONSELING INDIVIDU DI KELAS VII B DAN D SMPN 15 BANJARMASIN
}

\author{
Khairunnisa, Muhammad Yuliansyah, Aminah \\ Universitas Islam Kalimantan Muhammad Arsyad Al-Banjari \\ E-mail: k.ica1298@gmail.com
}

\begin{abstract}
ABSTRAK
Tujuan penelitian ini adalah untuk mengetahui hubungan antara persepsi siswa terhadap bimbingan dan konseling dengan minat siswa mengikuti layanan konseling individu di kelas VII B dan D SMPN 15 Banjarmasin. Latar belakang penelitian ini adalah adanya berbagai macam pandangan atau persepsi siswa terhadap BK di sekolah sehingga hal tersebut dapat mempengaruhi minat siswa mengikuti layanan konseling individu. Penelitian ini merupakan penelitian kuantitatif dengan desain korelasional dengan menggunakan teknik analisis Pearson Product Moment pada program SPSS 26. Sampel yang di gunakan ada 52 orang dari jumlah populasi 60 orang siswa VII B dan VII D dengan teknik simple random sampling. Teknik pengumpul data menggunakan dua buah skala likert melalui kuesioner yang di sebar kepada siswa melalui link WhatsApp. Uji validitas kuesioner menggunakan Pearson Product Moment dan uji reliabilitas menggunakan Cronbach Alpha. Hasil penelitian menunjukan bahwa ada hubungan positif yang signifikan antara persepsi siswa terhadap bimbingan dan konseling dengan minat siswa mengikuti layanan konseling individu pada kelas VII B dan VII D SMPN 15 Banjarmasin dengan nilai signifikan 0,001 $<0,05$ dan pearson correlation $0,448>\mathrm{r}_{\text {tabel }}$ pada taraf $5 \% 0,273$. Dengan demikian, hipotesis $\mathrm{H}_{1}$ di terima. Sehingga berarti bahwa persepsi siswa terhadap bimbingan dan konseling memiliki hubungan dengan minat siswa mengikuti layanan konseling individu.
\end{abstract}

Kata Kunci: Persepsi siswa; Minat siswa; Konseling Individu

\begin{abstract}
The purpose of this study was to determine the relationship between students 'perceptions of guidance and counseling with students' interest in participating in individual counseling services in class VII B and D of SMPN 15 Banjarmasin. The background of this research is the existence of various kinds of views or perceptions of students towards BK at school so that it can affect students' interest in participating in individual counseling services. This research is a quantitative study with a correlational design using the Pearson Product Moment analysis technique in the SPSS 26 program. The sample used was 52 people from a total population of 60 students VII B and VII D with simple random sampling technique. The data collection technique uses two scales through a questionnaire distributed to students via the WhatsApp link. Test the validity of the questionnaire using Pearson Product Moment and reliability test using Cronbach Alpha. The results showed that there was a significant positive relationship between students 'perceptions of guidance and counseling with students' interest in participating in individual counseling in class VII B and VII D of SMPN 15 Banjarmasin with a significant value of $0.001<0.05$ and Pearson correlation 0.448> r table at level 5. \% 0.273. Thus, hypothesis H1 is accepted. So it means that students 'perceptions of guidance and counseling have a relationship with students' interest in participating in individual counseling services.
\end{abstract}

Keywords: Student perceptions; Student interest; Individual Counseling

Dipublikasikan Oleh :

UPT Publikasi dan Pengelolaan Jurnal

Universitas Islam Kalimantan Muhammad Arsyad Al-Banjari Banjarmasin 
Khairunnisa, Muhammad Yuliansyah, Aminah

Jurnal Bimbingan dan Konseling Ar-Rahman

Volume 6, Nomor 2, Tahun 2020

e-ISSN 2477-6300

\section{PENDAHULUAN}

Dalam dunia pendidikan tidak jarang siswa mengalami permasalahan akibat dari adanya perubahan lingkungan sosial. Di usia anak SMP yang menginjak masa remaja akan sering menemukan masalah baik dalam bidang pribadi, sosial, belajar, dan karir. Wahyuni (2011) menyebutkan masalah siswa sering kali di temukan seperti sulitnya belajar, hubungan pertemanan, sulitnya penyesuaian diri, perilaku tidak menyenangkan, hingga permasalahan keluarga. Hal ini baik secara langsung ataupun tidak akan mempengaruhi dan menimbulkan masalah bagi siswa itu sendiri. Bimbingan dan konseling sebagai bagian dari pendidikan mempunyai peran penting untuk membantu seluruh siswa dalam menyelesaikan masalah yang di hadapi.

Masfufah (2013) menyebutkan bimbingan dan konseling adalah proses pemberian bantuan kepada individu yang dilakukan secara berkesinambungan, agar individu itu dapat memahami dirinya, mampu mengarahkan diri dan memiliki tindakan sesuai dengan tuntutan dan keadaan lingkungan. Dalam pemberian bantuan dapat dilakukan melalui pelaksanaan layanan salah satunya konseling individu. Pelaksanaan konseling individu di sekolah dapat terlaksana dengan baik jika setiap siswa memiliki minat secara sukarela untuk berkonseling. Crow and Crow (dalam Wahyuni, 2011) menyebutkan bahwa minat adalah dorongan yang menimbulkan individu memberikan perhatian atau ketertarikan kepada orang atau suatu kegiatan tertentu. Minat siswa dalam mengikuti konseling individu tentunya juga dapat di pengaruhi oleh adanya persepsi yang ada dalam diri siswa.

Rachmadhani (2016) menyebutkan persepsi merupakan cara orang memandang dunia ataupun segala sesuatu yang ada pada lingkungan sekitar, dan merupakan bagian penting dari proses terbentuknya perilaku individu. Layanan konseling individu yang di laksanakan di sekolah selama ini kurang di minati siswa karena berbagai macam persepsi terhadap bimbingan dan konseling. Guru BK sebagai sosok guru yang paling dilihat dalam dunia bimbingan dan konseling harus dapat menjadi seorang sahabat bagi siswa agar dengan mendekatkan diri dengan siswa secara baik maka persepsi-persepsi negatif terhadap BK dapat di hilangkan dan di gantikan dengan persepsi yang positif.

Berdasarkan hasil observasi di SMPN 15 Banjarmasin, persepsi siswa khususnya di kelas VII B dan VII D berupa persepsi negatif dan positif. Persepsi negatif dapat di contohkan ketika seorang siswa dipanggil ke ruang BK akan memunculkan persepsi bahwa siswa itu merupakan siswa yang bermasalah, ditambah lagi seringnya siswa melihat dan mendengar jika guru BK sering memberikan hukuman, guru BK kurang ramah dan menakutkan. Namun, tidak sedikit yang memiliki pandangan guru BK memiliki sifat keibuan, menyenangkan, dan selalu ramah kepada siswa.

Masfufah (2013) pada penelitiannya menyebutkan siswa yang berminat mengikuti konseling secara sukarela jumlahnya sangat sedikit. Guru BK di sekolah tersebut lebih sering menyebutnya menjemput bola yang artinya memanggil siswa langsung ke ruang BK. Karena siswa yang sering mengikuti konseling individu merupakan siswa yang telah melanggar peraturan sekolah. Persepsi siswa tentu saja akan mempengaruhi minat siswa itu dalam mengikuti konseling individu. Kurniati (2016) pada penelitiannya yang berjudul hubungan antara persepsi siswa tentang kinerja guru BK dengan minat mengikuti layanan konseling individu pada siswa kelas XI dengan hasil penelitian menunjukan ada hubungan positif dan signifikan antara variabel.

Pada dasarnya layanan konseling individu terselenggara atas kehendak diri siswa sendiri. Barokah (2017) menyebutkan konseling individu merupakan bantuan yang di berikan oleh konselor atau guru BK kepada konseli atau siswa dengan tujuan berkembangnya potensi siswa, siswa mampu mengatasi permasalahannya sendiri, dan dapat menyesuaikan diri secara positif. Konseling individu efektif dilakukan untuk menggali permasalahan yang dimiliki siswa karena siswa dapat menceritakan permasalahannya secara pribadi kepada guru BK tanpa di ketahui orang lain sesuai dengan asas kerahasiaan didalam bimbingan dan konseling. Bahri (2018) salah satu syarat terjadinya konseling yang baik ialah adanya kesadaran diri sendiri dari siswa. Sehingga minat siswa secara sukarela dalam mengikuti konseling dapat mempengaruhi pelaksanaan konseling itu sendiri.

Berdasarkan hasil observasi dan penelitian terdahulu menjadi alasan untuk meneliti persepsi siswa terhadap bimbingan dan konseling dengan minat siswa mengikuti layanan konseling individu dengan tujuan untuk mengetahui ada atau tidaknya adanya hubungan antara persepsi siswa terhadap bimbingan dan konseling dengan minat siswa mengikuti layanan konseling individu di kelas VII SMPN 15 Banjarmasin.

\section{METODE}

Penelitian ini merupakan penelitian kuantitatif dengan desain korelasional. Soesilo (dalam Azariya, Soesilo, Setyorini, 2020) menyatakan bahwa penelitian korelasi merupakan penelitian yang dilakukan untuk membuktikan 
Khairunnisa, Muhammad Yuliansyah, Aminah Jurnal Bimbingan dan Konseling Ar-Rahman Volume 6, Nomor 2, Tahun 2020

e-ISSN 2477-6300

sejauh mana keterkaitan suatu hubungan antara variabel dengan variabel lainnya.

Populasi dalam penelitian ini adalah siswa kelas VII B \& D SMPN 15 Banjarmasin yang berjumlah 60 orang siswa. Gay, Mills, Airasian (dalam Alwi, 2015) menyebutkan penelitian yang menggunakan metode korelasional paling tidak memerlukan sampel minimal 30 orang responden. Sehingga pada penelitian ini dari jumlah populasi didapatkan sampel sebanyak 52 orang pada taraf $5 \%$. Teknik sampling yang di gunakan adalah simple random sampling atau pengambilan sampel secara sederhana.

Teknik pengumpulan data menggunakan teknik kuesioner dengan jenis kuesioner tertutup. Instrumen yang di gunakan ialah kuesioner dengan jenis skala pengukuran skala model likert. Sugiyono (2011) dalam penelitian skala likert dapat di gunakan untuk mengukur sikap, pendapat, atau persepsi individu atau kelompok orang tentang fenomena sosial. Penelitian ini menggunakan dua buah skala, yaitu skala persepsi siswa terhadap BK yang terdiri dari 40 item pernyataan dan di bagi menjadi 22 item favorable dan 18 item unfavorable. Skala minat siswa mengikuti konseling individu yang terdiri dari 40 item terbagi 28 item favorable dan 12 item unfavorable.

Teknik analisis data yang di gunakan ialah teknik korelasi product moment pearson dengan bantuan program SPSS 26. Selain itu dalam penelitian ini juga dilakukan uji prasyarat, yaitu uji normalitas dan uji linearitas.

\section{HASIL DAN PEMBAHASAN}

Sugiyono (dalam Romadhon, 2016) menyebutkan validitas merupakan derajat ketetapan antara data yang terjadi pada obyek penelitian dengan daya yang dilaporkan oleh peneliti. Uji ini dilakukan untuk menyeleksi item-item yang valid dan item yang tidak valid. Item di katakan valid jika nilai $\mathrm{r}_{\text {hitung }}>\mathrm{rt}_{\mathrm{abel}}$, dan di katakan tidak valid jika $r_{\text {hitung }}<r_{\text {tabel. }}$ Pada penelitian ini $r_{\text {tabel }}$ didapatkan dari $(\mathrm{N}=$ df-2) sehingga $(52-2=50)$ pada tabel 50 didapatkan 0,273. Hasil uji skala persepsi didapatkan 2 item yang tidak valid yaitu item 2 dan 28. Dimana item 2 memiliki $r_{\text {hitung }} 0,243$ dan item 28 memiliki $\mathrm{r}_{\text {hitung }} 0,249$ sehingga kedua item tidak valid karena $<0,273$. Sedangkan hasil uji validitas skala minat siswa didapatkan satu item yang tidak valid dengan $r_{\text {hitung }} 0,174<0,273$.

Ghozali (dalam Putri, Marsiwi, Ulfah, 2018) menyebutkan kuesioner di katakan baik atau reliabel jika jawaban terhadap pernyataan stabil atau konsisten. Item pernyataan tersebut di aktakan reliabel jika nilai Cronbach Alpha > 0,06 dan di katakan tidak reliabel jika nilai Cronbach Alpha < 0,06 . Hasil uji reliabilitas skala persepsi dengan nilai Cronbach Alpha 0,949>0,06 dan skala minat memiliki nilai Cronbach Alpha 0,938>0,06, sehingga kedua skala dinyatakan reliabel.

Pada Penelitian ini dilakukan pada dua buah kelas VII SMPN 15 Banjarmasin, yaitu VII B dan VII D. Dari hasil analisis deskriptif diketahui distribusi persepsi siswa dan minat siswa dalam mengikuti layanan konseling individu, sebagai mana terlihat pada tabel 1 dan 2.

Berdasarkan tabel 1 diketahui distribusi persepsi siswa terhadap bimbingan dan konseling dari jumlah sampel 52 orang didapatkan 35 orang responden atau $67 \%$ berada pada kategori tinggi dan 17 orang atau $32,7 \%$ berada pada kategori sedang serta $0 \%$ untuk di kategori rendah. Pada tabel 2 distribusi minat siswa mengikuti konseling individu terdapat 37 responden atau $71,2 \%$ pada kategori tinggi, 15 orang atau $28,8 \%$ berada pada kategori sedang dan $0 \%$ berada pada kategori rendah. Sehingga dari hasil tersebut persepsi siswa dan minat siswa dominan berada pada kategori.

Tabel 1. Distribusi Persepsi Siswa Terhadap Bimbingan dan Konseling

\begin{tabular}{llrrrr}
\hline & & Frequency & Percent & Valid Percent & Cumulative Percent \\
\hline \multirow{2}{*}{ Valid } & Sedang & 17 & 32,7 & 32,7 & 32,7 \\
& Tinggi & 35 & 67,3 & 67,3 & 100,0 \\
\cline { 2 - 6 } & Total & 52 & 100,0 & 100,0 & \\
\hline
\end{tabular}

Tabel 2. Distribusi Minat Siswa Mengikuti Konseling Individu

\begin{tabular}{llrrrr}
\hline & & Frequency & Percent & Valid Percent & Cumulative Percent \\
\hline \multirow{2}{*}{ Valid } & Sedang & 15 & 28,8 & 28,8 & 28,8 \\
& Tinggi & 37 & 71,2 & 71,2 & 100,0 \\
\cline { 2 - 6 } & Total & 52 & 100,0 & 100,0 & \\
\hline
\end{tabular}


Khairunnisa, Muhammad Yuliansyah, Aminah Jurnal Bimbingan dan Konseling Ar-Rahman Volume 6, Nomor 2, Tahun 2020

e-ISSN 2477-6300

Uji prasyarat pada penelitian ini menggunakan uji normalitas Kolmogorov Smirnov dengan melihat nilai signifikansi pada unstandardized residual, jika nilai signifikansi > 0,05 maka berdistribusi normal, dan jika nilai signifikansi < 0,05 maka tidak normal. Dari hasil analisis didapatkan data nilai signifikansi 0,200> 0,05, sehingga nilai residual berdistribusi normal. Pada penelitian uji linearitas dilihat dari nilai signifikansi deviation from linearity, jika nilai signifikansi deviation from linearity $>0,05$ maka hubungan linear dan begitu pula sebaliknya. Dari hasil analisis uji linear didapatkan nilai deviation from linearity $0,155>0,05$ maka dapat di simpulkan bahwa ada hubungan yang linear antara variabel bebas dan variabel terikat.

Untuk menguji hipotesis pada penelitian ini menggunakan teknik analisis korelasi product moment pearson. Uji hipotesis bertujuan untuk mengetahui ada atau tidaknya hubungan antara persepsi siswa terhadap bimbingan dan konseling dengan minat siswa mengikuti layanan konseling individu di kelas VII B dan D SMPN 15 Banjarmasin. Analisis dilakukan menggunakan SPSS 26 for windows dengan dasar keputusan jika nilai < 0,05 maka berhubungan atau membandingkan nilai $r_{\text {hitung dengan }} r_{\text {tabel }}$. Jika nilai $r_{\text {hitung }}>r_{\text {tabel }}$ maka berhubungan.

Tabel 3. Analisis Korelasi Antara Persepsi Siswa dengan Minat Siswa

\begin{tabular}{|c|c|c|c|}
\hline & & Persepsi & Minat \\
\hline \multirow[t]{3}{*}{ Persepsi } & Pearson Correlation & 1 &, $448^{* *}$ \\
\hline & Sig. (2-tailed) & & ,001 \\
\hline & $\mathrm{N}$ & 52 & 52 \\
\hline \multirow[t]{3}{*}{ Minat } & Pearson Correlation &, $448^{* *}$ & 1 \\
\hline & Sig. (2-tailed) & ,001 & \\
\hline & $\mathrm{N}$ & 52 & 52 \\
\hline
\end{tabular}

**. Correlation is significant at the 0.01 level (2-tailed).

Berdasarkan data pada tabel 3 di atas di ketahui nila $\mathrm{r}=0,448>0,273$ dengan nilai signifikansi $0,001<0,05$, sehingga dapat di simpulkan bahwa ada hubungan positif yang signifikan antara persepsi siswa terhadap bimbingan dan konseling dengan minat siswa mengikuti layanan konseling individu di kelas VII B dan D SMPN 15 Banjarmasin.

Dari data hasil penelitian diperoleh nilai Pearson Correlation atau $\mathrm{r}$ adalah 0,448. Jika di bandingkan dengan $r_{\text {tabel }}$ sebesar 0,273 pada taraf $5 \%$ maka pearson correlation > rtabel $(0,448>$ 0,273 ) dinyatakan berhubungan, begitu pula dengan nilai signifikansi $0,001<0,05$ maka variabel berhubungan. Korelasi antara persepsi siswa dengan minat siswa berada pada korelasi tingkat sedang berkisar antara 0,400 - 0,599. Selain itu hasil dari perhitungan terlihat nilai pearson correlation bernilai positif karena tidak memiliki tanda (-) di depan angka sehingga bentuk hubungan yang di hasilkan positif. Hubungan positif yang di maksud ialah semakin tinggi persepsi siswa maka akan semakin tinggi pula minat siswa dalam mengikuti layanan konseling individu. Sebaliknya, semakin rendah persepsi siswa maka akan semakin rendah pula minat siswa dalam mengikuti layanan konseling individu.

Dari hasil data di atas di ketahui bahwa persepsi positif siswa yang tinggi memiliki hubungan secara langsung dalam mempengaruhi minat siswa dalam mengikuti layanan konseling individu. Rakhmat dkk (dalam Ardiwita 2014), menyebutkan persepsi dapat di pengaruhi oleh pengalaman individu, motivasi, dan kepribadian. Pengalaman setiap siswa yang baik akan adanya BK baik itu menyangkut layanan ataupun guru BK di sekolah akan membuat perasaan senang sehingga munculah persepsi positif. Slameto (dalam Istiati, 2013) minat memiliki berbagai macam salah satunya minat yang di wujudkan. Seorang individu dapat mengungkapkan minatnya terhadap sesuatu bukan hanya melalui kalimat akan tetapi dapat dilakukan melalui perbuatan atau tindakan. Dengan persepsi siswa yang berada pada kategori tinggi menjadi salah satu faktor tingginya minat siswa sehingga dalam tindakannya pun siswa akan berminat secara sukarela mengikuti konseling individu.

Sejalan dengan hasil penelitian yang di lakukan oleh Rina Istiati (2013) yang menyatakan persepsi siswa terhadap guru BK yang baik akan 
Khairunnisa, Muhammad Yuliansyah, Aminah

Jurnal Bimbingan dan Konseling Ar-Rahman

Volume 6, Nomor 2, Tahun 2020

e-ISSN 2477-6300

berdampak terhadap minat siswa dalam mengikuti layanan konseling individu dengan hasil penelitiannya berada pada kategori tinggi.

Hasil penelitian ini juga mendukung penelitian terdahulu yang dilakukan oleh Refian Hantika Sari \& Nadhirotul Laily (2011) peneliti tersebut mendapatkan hasil bahwa ada hubungan antara persepsi dengan minat konseling pada siswa keals X SMK PGRI Gresik sama halnya dengan hasil yang didapatkan pada penelitian ini. Sehingga dari uraian di atas dapat dinyatakan hipotesis penelitian yang menyatakan ada hubungan yang signifikan antara persepsi siswa terhadap bimbingan dan konseling dengan minat siswa mengikuti layanan konseling individu di terima.

\section{PENUTUP}

Berdasarkan hasil analisis data yang diperoleh dalam penelitian ini dapat di simpulkan bahwa ada hubungan positif yang signifikan antara persepsi siswa terhadap bimbingan dan konseling dengan minat siswa mengikuti layanan konseling individu di kelas VII B dan D SMPN 15 Banjarmasin.

Dalam penelitian yang telah dilakukan pada siswa kelas VII B dan D SMPN 15 Banjarmasin, peneliti menyarankan beberapa hal sebagai berikut: (1) sekolah dapat meningkatkan kualitas BK yang ada di sekolah lebih khusus lagi dalam pemberian layanan sehingga siswa semakin berminat dalam mengikuti layanan konseling; (2) Guru BK dapat mempertahankan persepsi siswa yang positif terhadap BK dengan cara menjadi sahabat siswa dan meningkatkan kinerja secara optimal; (3) Bagi peneliti selanjutnya jika melakukan penelitian dengan tema yang sama diharapkan menggunakan variabel yang berbeda seperti fokus kepada persepsi siswa khususnya terhadap guru BK.

\section{REFERENSI}

Alwi, I. (2015). Kriteria Empirik Dalam Menentukan Ukuran Sampel Pada Pengujian Hipotesis Statistika dan Analisis Butir. Jurnal Formatif, 2 (2), 140-148

Ardiwita. (2014). Hubungan Antara Persepsi Terhadap Layanan Konseling Individual Dengan Minat Berkonseling Pada Siswa SMKN 1 Kota Bengkulu. Skripsi, Universitas Bengkulu. Di akses dari : http://repository.unib.ac.id/8360/2/I\%2CII \%2CIII\%2CII-14-arw.FK.pdf.

Azariya, I,. Soesilo, T.D., \& Setyorini. (2020). Hubungan Antara Perkembangan Moral Dengan Perilaku Prososial Siswa Kelas X Rekayasa Perangkat Lunak SMK Negeri 1
Tengaran. Jurnal Bimbingan dan Konseling Ar-Rahman, 6 (1), 68-73

Bahri, A.N. (2018). Hubungan Persepsi Tentang Guru BK dengan Minat Berkonsultasi pada SMK Negeri 7 Medan. Skripsi, Universitas Medan Area. Di akses dari : http://repository.uma.ac.id/bitstream/12345 6789/9818/1/Annisa\%20Nur\%20Bahri\%20 -\%20Fulltext.pdf

Barokah, H.A. (2017). Hubungan Antara Persepsi Siswa Terhadap Kinerja Guru BK dengan Kepercayaan Melakukan Konseling Individual. Jurnal Riset Mahasiswa Bimbingan dan Konseling, 3 (8), 429 - 441

Istiati, R. (2013). Korelasi Antara Kepribadian Konselor Dengan Minat Siswa Mengikuti Layanan Konseling Individu di SMA Negeri 1 Kendal Kabupaten Kendal Tahun Ajaran 2013/2014. Skripsi, Universitas Negeri Semarang. Di akses dari: https://lib.unnes.ac.id/17178/1/1301406520. pdf

Kurniati, W. (2016). Hubungan Antara Persepsi Siswa Tentang Kinerja Guru BK Dengan Minat Mengikuti Layanan Konseling Individu Pada Siswa Kelas XI Di SMA Negeri 1 Gondang Kabupaten Sragen Tahun Ajaran 2016/2017. Skripsi, Universitas Negeri Semarang. Di akses dari : https://lib.unnes.ac.id/28765/1/1301412002. pdf

Masfufah, L. (2013). Hubungan Antara Persepsi Siswa Terhadap Layanan Konseling Individu dan Kinerja Konselor Dengan Motivasi Siswa dalam Melanjutkan Hubungan Konseling Individu. Jurnal BK UNESA, 01 (01), 200 - 207

Putri, S.O.D.A., Marsiwi, D., \& Ulfah, I.F. (2018). Penekaan Anggaran, Kapasitas Individu dan Group Cohesiveness Terhadap Kecenderungan Menciptakan Budgatary Pada Organisasi Sektor Publik (Studi Empiris Pada Organisasi Perangkat Daerah Kabupaten Wonogiri). Jurnal Ekonomi, Manajemen, dan Akuntansi, 2 (1), 56 - 66

Rachmadhani, D.P. (2016). Studi Deskriptif Persepsi Peserta Didik terhadap Guru Bimbingan dan Konseling dalam Pelaksanaan Layanan Konseling Individual. Psikopedagogia, 5 (1), 57-65

Romadhan, A.F. (2016). Faktor-faktor Yang Mempengaruhi Minat Dan Motivasi Memafaatkan Layanan Bimbingan dan Konseling Pada Siswa SMA Negeri 10 Yogyakarta. Skripsi, Universitas Negeri Yogyakarta. Di akses dari: 
Khairunnisa, Muhammad Yuliansyah, Aminah Jurnal Bimbingan dan Konseling Ar-Rahman Volume 6, Nomor 2, Tahun 2020

e-ISSN 2477-6300

https://core.ac.uk/download/pdf/78034759. pdf

Sari, R.H., \& Laily, N. (2011). Hubungan Antara Kecenderungan Persepsi Terhadap Guru BK Dengan Tingkat Minat Konsultasi Pada Siswa Kelas X SMK PGRI 1 Gresik. Jurnal Psikosains, 3 (2), 1 - 12

Sugiyono. (2011). Metode Penelitian Kuantitatif, Kualitatif, dan $R \& D$. Bandung : Alfabeta

Wahyuni, T. (2011). Hubungan Antara Persepsi Tentang Layanan Bimbingan Konseling dan Minat Berkonsultasi Siswa Sekolah Menengah Atas Negeri 10 Pekanbaru. Skripsi, Universitas Islam Negeri Sultan Syarif Kasim Riau Pekanbaru. Di akses dari : http://repository.uinsuska.ac.id/518/1/2011_2011836.pdf. 